\title{
Mediterranean Diet and Health Promotion: evidence and current concerns
}

Authors:

Tozzi Ciancarelli Maria Giuliana ${ }^{1}$

Di Massimo Caterina ${ }^{2}$

De Amicis Daniela ${ }^{2}$

Ciancarelli Irene $e^{2,3}$

\section{Affiliations:}

1 Department of Human Sciences University of L'Aquila - San Salvatore Hospital, Delta Building 6, Loc Coppito, 67100 L'AQUILA - ITALY

2 Department of Clinical Medicine, Public Health, Life Sciences and Environment - University of L'Aquila San Salvatore Hospital, Delta Building 6, Loc Coppito, 67100 L'AQUILA ITALY

3 Nova Salus Nursing and Rehabilitation Center - 67059 Trasacco (L'Aquila) - Italy

\section{Correspondence author:}

Maria Giuliana Tozzi Ciancarelli

Department of Human Sciences University of L'Aquila - San Salvatore Hospital, Delta Building 6, Loc Coppito;

E-mail: mariagiuliana.tozzi@univaq.it

Keywords: Mediterranean diet, health promotion, inflammation, oxidative stress, environmental pollutants

\begin{abstract}
The Mediterranean diet (MD) is a dietary pattern described by Ancel B. Keys in the 1950s as a typical dietary habit of some populations bordering the Mediterranean sea in the south of Europe characterized by frugal living style. Findings of the Seven Country Study showed that people faced in the Mediterranean area had a reduced incidence of cardiovascular and metabolic disease, cancer and age-related diseases. The mechanisms through which the MD exerts its health benefit and prevents the onset of several diseases are not completely clarified because of various and complex aspects. Several studies suggest that the claimed benefits of the MD dietary pattern is mainly linked to decreased inflammation and oxidative stress, strongly related to each other and involved in many chronic diseases. The high content of compounds with antioxidant and anti-inflammatory activity present in most foods of the MD pattern has been considered effective for the improvement of many functions and parameters, therefore useful for the maintenance of the health status and the prevention of many chronic diseases. However, the extensive metabolism to which antioxidant compounds are subjected, once ingested with foods, reduces their antioxidant activity within the systemic circulation and tissues and their concentrations are very low in comparison with endogenous antioxidants. Foods produced for human nutrition have significant consequences for both the environment and the health of a specific population, and, in turn, the environment may address food choices and affect eating habit. The MD is a sustainable diet model that presents a very low environmental footprint, promotes the bio-diversity and protects human health and well-being. However, we must not ignore the planet changes and global environmental aspects that might convert the MD into a theoretical eating model far away from that described by Keys.
\end{abstract}




\section{Introduction}

Strong evidence highlights profound lifestyle changes of the world's population as a consequence of global socio-economic shifts, evident even in low- and middleincome developing countries (Traill et al. 2014, Fazel-Tabar Malekshah et al. 2016, Mehio Sibai et al. 2010, Fuster \& Kelly 2010, Schwingshackl \& Hoffmann 2015). Several studies (Loef \& Walach 2012, van Dam et al. 2008, Khaw et al. 2008) showed that modern food production/distribution and increased industrialization of agro-food systems have influenced significantly the worldwide dietary habit and nutritional components of eating patterns with a strong impact on nutritional outcomes (Owolabi et al. 2016, World Health Organization 2011, Hawkes 2006, Garnett et al. 2013, Knight et al. 2016). It is widely demonstrated that eating habit as a whole, rather than an individual nutrient or groups of them, interacts with health status (Schulze \& $\mathrm{Hu}$ 2002, Jacques \& Tucker 2001, Fung et al. 2001) and may have a significant influence on modifiable risk factors of noncommunicable diseases (NCDs), which are reaching epidemic proportions worldwide. The consumption of high-caloric obesogenic foods, endemic to industrialized nations and increased in the developing countries on which economic growth and globalization have triggered the phenomenon known as "nutrition transition" (Belahsen 2014, Gayathri et al. 2016), caused a progressive abandon of traditional diet patterns and has determined, at the same time, a very frequent adoption of unhealthy eating habit so increasing the susceptibility to the onset of diet-related chronic diseases (Hawkes 2006). Conversely, as recently observed, dietary behaviour should not disregard the use of local foods which are naturally cultivated in a specific geographic region and comply with important ecological, economic and cultural aspects (Lacoppidan et al. 2015, Gayathri et al. 2016, Iriti \& Vitalini 2012). It is well known that habitual consumption of foods high in fats and sweeteners may contribute significantly to the onset of NCDs by increasing the burden of multiple risk factors such as inflammation, hypertension, hyperglycemia, dyslipidemia and obesity (Menotti et al 2012, Schwingshackl \& Hoffmann 2015). Instead, high compliance to healthy diets, as assessed by validated tools/scales evaluating diet quality (Donini et al. 2016, Schwingshackl \& Hoffmann 2015, Mertens et al. 2017) is positively linked with longevity, may interfere on all-cause mortality and lower the risk for developing cardiovascular events (CVD) and stroke, cancer and neurodegenerative disease (World Health Organization 2003, Chiuve et al. 2012, Harmon et al. 2015). There is no doubt that aging-associated diseases are currently and will continue to be a worldwide public health burden in the near future. Unhealthy dietary habit by increasing the susceptibility to age-dependent inflammation and oxidative stress (Di Massimo et al. 2006, Castellani et al. 2016) amplifies the burden of the risk factors in the onset of NCDs. Therefore, the world challenge for the immediate future is promoting human health on a planet where the global life expectancy and the spread of diseases linked to unhealthy diets are increasing and planet resources undergo a progressive depletion. It is known that an adequate, well balanced diet combined with regular physical activity is a cornerstone of good health status and that nutrition interferes positively with the individual disease risk profile at both primary and secondary level of prevention (Gostin et al. 2017, Kones 2011, Lloyd-Jones et al. 2009, Lloyd-Jones et al. 2010, Reedy et al. 2014). The 2013 World Health Assembly endorsed the Global Action Plan on Noncommunicable Diseases 2013-2020 "which proposed a sustainable set of actions for Member States, international partners and the WHO Secretariat to prevent NCDs, promote healthy diets and physical activity, 
and to attain the nine voluntary global NCD targets by 2025. The nine targets include halting the rise in diabetes and obesity in adults and adolescents as well as the increase of childhood overweight and obesity by 2025" (World Health Organization 2014). On the basis of scientific evidence and thematic areas on health promotion in the world's population, measures and interventions have been developed in numerous countries to develop effective strategies according to food-based dietary guidelines and validated dietary indexes and with the aim of reducing the risk burden related to unhealthy dietary patterns (Schwingshackl \& Hoffmann 2015, World Health Organization 2003, Wirt \& Collins 2009, Watson et al. 2010). In a large case-control study of acute myocardial infarction (AMI) showing the association between dietary patterns and a dietary risk score with AMI and in different regions of the world (Iqbal et al. 2008), western, prudent and oriental dietary patterns have been considered. The western dietary habit, characterized by fried foods, salty snacks, eggs, and meat, was associated with an increased risk for CVD in all countries of the world; the oriental pattern, high in intake of tofu and soy, showed no relationship with AMI risk, whereas the prudent pattern, high in fruits and vegetables, was associated with a lower CVD risk. Therefore, the increased consumption of vegetables and fruits may have the potential for lower incidence and mortality from CVD. The adoption of a Mediterranean-type diet which is characterized by a high consumption of vegetables and fruits, confirms its health value by favouring many beneficial outcomes and justifies its effectiveness in decreasing the risk for the most important chronic diseases (Lairon 2007, Fung et al. 2009, Sofi et al. 2008).

The present study provides an overview of the evidence on healthy effect of Mediterranean diet (MD) and on some aspects which may limit and interfere with its beneficial characteristics.

\section{The Mediterranean Diet: the scientific evidence on health promotion}

As well known, the traditional MD is a dietary pattern described by Ancel B. Keys in the years 50-60 of the last century as a typical, simple eating habit of some populations bordering the Mediterranean sea accustomed to a frugal living style due to the severe economic crisis following the Second World War and a low technology level (Keys et al. 1986, De Lorgeril et al. 1999, World Heart Organization Study Group 1990). The results of the Seven Country Study, legendary in the field of medicine, showed that people faced in the Mediterranean area, compared with the other populations analyzed in the study, had a reduced incidence of cardiovascular disease and a lower degree of meta-inflammation, which, as known, is an important feature of the aging process and age-related diseases (Keys et al. 1986, Di Massimo et al. 2006, Starr et al. 2009). The scientific research has largely confirmed the health-promoting effects of the MD highlighted by the pioneer Seven Country Study (Vareiro et al. 2009, Bach-Faig et al. 2011), and additional positive effects of the MD for maintaining the health status have been also observed for diseases other than CVD such as cognitive impairment, depression, and neurodegenerative diseases (Knight et al. 2016, Reedy et al. 2014, Sofi et al. 2008, Psaltopoulou et al. 2013, Psaltopoulou et al. 2008). Previous studies showed that a high adherence to the MD pattern may be associated with an improvement of endothelial function and to decreased plasma levels of inflammatory and oxidative stress markers, known to be involved as mediators of several diseases (Vogel et al. 2000, Medina-Remón et al. 2017, Calcabrini et al. 2017, Ciancarelli et al. 2016). Interestingly, evidence was provided that a two point increase in the 
score for adherence to the MD is sufficient to reduce the incidence of Parkinson's and Alzheimer's disease (Sofi et al. 2008). The MD patterns differ among the countries bordering the Mediterranean sea because of a variety of typical socio-cultural traditions, agricultural production and economy (Dernini \& Berry 2015, Noah \& Truswell 2001), but some common and specific features may be individualized. High consumption of seasonal fruit and vegetables, whole cereals and legumes, moderate/very low intake of dairies and animal products are common eating habit of Mediterranean populations devoted mainly in the past to agricultural work (Keys et al. 1986, Knoops et al. 2004, Sofi et al. 2014). Remarkably, the main source of dietary fat is represented by extra-virgin olive oil. Globally, the MD is rich in monounsaturated fatty acids, primarily oleic acid, dietary fibers, antioxidant compounds such as polyphenols, and a high ratio of omega-3 to omega-6 polyunsaturated fatty acids (Medina-Remón et al. 2017). Core components of traditional MD are also aromatic herbs and spices, that seem to increase the healthy characteristics of this virtuosos eating habit (Keys et al. 1986, Vallverdú-Queralt et al. 2014, Bower et al. 2016), regular but moderate red wine consumption often consumed with meals, food palatability/preparation and, as elegantly observed by Iriti \& Vitalini (2012), "eating together around the same table: 'we do not sit at table to eat, but to eat together' (Plutarch) (UNESCO nomination file $n$. 00394)". Indeed, the MD, intangible heritage of humanity, is not a banal list of foods with different potential on health promotion but it is a complex model of eating pattern unquestionably integrated with the culture, lifestyle, tradition, family ties, and social relations. In the Ikaria Study, the percentage of people over the age of 90 years living in the Greek island of Ikaria was much higher than the European population average. The majority of the subjects observed regular physical activity, healthy eating habits (avoidance of smoking and spirits, very low consumption of wine during meals), midday naps, frequent socializing, thereby showing that the link between virtuous lifestyle, frugal eating behaviour and the observance of traditions may favourably influence the aging process and life expectation (Panagiotakos et al. 2011). So far, the mechanisms of action through which the MD exerts its health benefit as a whole and prevents the onset of several diseases are not completely clarified because of various and complex aspects. Most of the studies identifying the possible mechanism by which the MD plays its beneficial potential have been carried out by assessing single nutrients or food groups. The results seem to confirm a significant relationship between the consumption of determined foods and a possible prevention of cardiovascular disease, diabetes, and cancer (Oliviero et al. 2015, McKay et al. 2010, Medina-Remón et al. 2017, Calcabrini et al. 2017, Korre et al. 2014). Large observational studies and randomized trials support that the claimed benefits of the MD pattern or of the consumption alone of its characterizing foods is mainly linked to reducing the impact of inflammation and oxidative stress which are strongly related to each other and are involved in the aging process and in a number of chronic diseases including diabetes, cardiovascular and neurodegenerative diseases, and cancer (Halliwell \& Gutteridge 1999, Medina-Remón et al 2017, Koloverou et al. 2016, Davis et al. 2017, Hernáez et al. 2017, Chrysohoou et al. 2004, Esposito et al. 2004, Colomer \& Menéndez 2006). Both nutritive and non-nutritive components of the MD show significant anti-inflammatory activities which influence the arachidonic acid cascade, the expression of some proinflammatory genes, and the activity of immune cells ( Preedy \& Watson 2015). Moreover, the high antioxidant potential due to the richness of polyphenols, flavonoids and stilbenes in foods and 
beverages may protect against oxidative stress, thereby preventing cellular oxidative reactions and scavenging reactive oxygen species (Tozzi Ciancarelli et al. 2011, Panagiotakos et al. 2004). Accordingly, a beneficial effect on oxidative stress-related diseases has been observed in response to the intake of nuts (Ros et al. 2004), pomegranates (Malik \& Mukhtar 2006), tomatoes (World Cancer Research Fund/American Institute for Cancer Research 2007), coffee (Andersen et al. 2006), tea (Cabrera et al. 2006), and red wine (Cordova et al. 2005). Moreover, recent findings suggest that a polyphenolrich diet is associated with decreased levels of inflammatory biomarkers and an improvement in cardiovascular risk factors such as low density lipoprotein-cholesterol, high density lipoprotein-cholesterol and systolic and diastolic blood pressure (Medina-Remón et al. 2017). In the PREDIMED Study, a long-term multicenter trial, subjects at cardiovascular risk were assigned to a low-fat diet and two different Mediterranean patterns, with olive oil or nuts. Consumption of the MD enriched with olive oil reduced levels of oxidized low density lipoprotein-cholesterol more than the nut-rich MD. Conversely, the latter was more effective in increasing high density lipoproteins and in decreasing triglyceride levels. (Fitó et al. 2007). Therefore, according to the mentioned studies, most of the food components characterizing the MD pattern seem to have functional properties and, as reported by one of the working definitions of functional foods (International Food Information Council 2012) "may provide a health benefit beyond basic nutrition and may play a role in reducing or minimizing the risk of certain diseases and other health conditions". Globally, available findings confirm the apparent positive effect of most of the food components of the MD pattern on a number of functions and parameters such as endothelial function, blood pressure, blood lipid profile and platelet responsiveness and the related cascade of events (Ortega 2006, Chrysohoou et al. 2004, Martínez-González et al. 2016, Calcabrini et al. 2017, Koloverou et al. 2016, Aparicio-Soto et al. 2016). Over the past few years, studies have suggested that the positive effects of the MD on health status could be ascribed not just or not so much to individual constituents but rather to the synergic and combined interaction between foods and their bioactive components which as a whole are the supporting structure of the MD (Menotti et al. 2012, Sofi et al. 2008, Sofi et al. 2014, Asif et al. 2013, Iriti \& Vitalini 2012). Many studies underline that health benefits are associated with strict adherence to the MD and strongly prove that an unhealthy eating habit, such as the intake of highly processed foods (Katz \& Meller 2014) represents an insidious risk factor for non-communicable diseases in both the developing and developed world (Caretto \& Lagattolla 2015, Alsaffar 2016).

Most dietary patterns which have been studied for their healthy properties (e.g. DASH, Mediterranean or Nordic diets) are based on very similar principles that respect the environment and can be easily achieved at the population level (Katz \& Meller 2014, Lacoppidan et al. 2015, Sacks et al. 1999). Particularly, considerable importance was attributed to the use of natural foods which should be prioritized over processed foods and industrially produced trans fats and simple sugars (Niebylski et al. 2015, Leclercq et al. 2009, Sette et al. 2011). Despite that clear recommendations on proper eating behaviour have been consistently emitted by governments and health agencies, the major challenge remains to change the current unhealthy and unsustainable dietary patterns in the general population around the world. Indeed, as recently observed, improving dietary habits of the population has proven extremely difficult, as well as encouraging people to adopt sustainable dietary changes which 
limit environmental impacts, beyond the mere nutritional value (Horgan et al. 2016).

\section{The Mediterranean Diet: current concerns}

There is a general agreement to believe that the health promotion due to a high adherence to MD may be ascribed to its strong influence on decreasing the inflammatory processes and increasing the antioxidant defenses, so counteracting the interactive relationships between inflammation, oxidative stress and related diseases (Mangge et al. 2014, Dai et al. 2008, Psaltopoulou et al. 2013 Reedy et al., 2014). The high content of compounds with antioxidant and anti-inflammatory activity present in most foods of the MD pattern (legumes, dried and fresh fruits, vegetables, fish, extra virgin olive oil) has been considered effective in counteracting cellular degeneration, proliferation of cancer cells, and improving the intestinal function as well as for regulating metabolic parameters (Sofi el al. 2014, Ortega, 2006, Aparicio-Soto et al. 2016, Reedy et al. 2014, Huang \& Davidge 2013). The identification and the evaluation of bioactive constituents of the MD are, therefore, crucial to confirm the MD pattern as an effective tool for the maintenance of health status and prevention of chronic diseases and cancer due, at least in part, to an unhealthy eating behaviour and lifestyle. Particular emphasis has been given to the protective effects of polyphenols, common food constituents of plant origin characterized by a variety and complexity of chemical structure responsible for their biological properties and bioavailability (Tapiero et al. 2002, D'Archivio et al. 2007). Several studies have tried to evaluate through which mechanisms polyphenol-rich foods could exert a health benefits and most of the findings underlined that their favourable influence on health status is due to powerful antioxidant activities of the polyphenol content in them (Hernáez et al.
2017, Fitò et al. 2007, Aparicio-Soto et al. 2016, Malik \& Mukhtar, 2006). Effectively, it has observed that after consumption of polyphenol-rich foods, blood plasma values of Total Antioxidant Capacity (TAC) may increase, shortly or after a little more time depending on polyphenol concentration in foods ingested and if they were beverages or solid foods (Hollman et al. 2011, Pellegrini et al. 2003, Pellegrini et al. 2006). Noteworthy, the effect was transient and blood plasma TAC values return to baseline values after a few hours (Hollman et al. 2011). Recently, some evidence has been provided on the possible differences between acute effects on some surrogate markers for cardiovascular risk following acute consumption of some polyphenol-rich foods and longer-term effects due to their chronic/habitual intake. Recent findings suggest that a chronic response of the vascular endothelium might be distinguished from the acute response and that chronic/regular intake of dietary polyphenols might result as a promising and effective nutritional strategy for health and diseases management (Miranda et al. 2016, Davinelli \& Scapagnini 2016). However, the possible mechanisms underlying the observed differences between acute and long-term effect on markers must still be confirmed (Sies 2010, Tozzi Ciancarelli et al. 2011). In the early 1990's, red wine gained great attention to explain the epidemiological observation on the low incidence of cardiovascular disease in French people, despite consuming a diet high on saturated fats ("the French paradox") (Renaud \& de Lorgeril, 1992). The Authors suggested that the inhibition of platelet reactivity by wine could have been one explanation for protection from coronary heart disease $(\mathrm{CHV})$ in France people. In the attempt to verify the attractive relationship between antioxidant activity of red wine non-alcoholic components and platelet's responsiveness, a plethora of interesting studies were published, but the results 
remain even today discordant and far from being conclusive (De Lange et al. 2003, Goldberg et al. 2003, Gresele et al. 2008, Tsang et al, 2005, Tozzi Ciancarelli et al. 2011). Bioavailability of polyphenols is limited and their concentrations within the systemic circulation and tissues are very low in comparison with endogenous antioxidants, such as uric acid or ascorbic acid (Sies 2010, Hollman et al. 2011, Ciancarelli et al. 2015). Therefore, they could be well below those needed to achieve the biological effects observed in vitro experiments or in laboratory animals. Notably, once ingested, the polyphenolic molecules undergo the extensive metabolism that reduces their antioxidant activity and leads to the presence within the circulation of a mixture of compounds whose bioactivity in the systemic circulation must be demonstrated. (Sies 2010, Hollman et al. 2011, Tarascou et al. 2010, Carlsen et al. 2010, Del Rio et al. 2010). Foods which are produced for human nutrition have significant consequences for both the environment and health of a given population (Sáez-Almendros et al. 2013) and, in turn, the environment may handle food choices and affect eating habit (Baroni et al. 2007). Climate changes, toxic emissions and greenhouse gas emissions have caused profound changes in the planet that are reflected on agriculture and food availability. Notably, food intake contributes substantially to our exposure to environmental contaminants. Food choices and agro-food-industry practices as well as trade policies should take due account of environmental footprints.

Heavy metals intake by human populations through the food chain are important environmental pollutants. Their presence in the atmosphere, soil and water, and bioaccumulation in the food chain even in traces could cause deleterious effects for human health (Islam $\mathrm{Eu}$ et al. 2007). Moreover, intensive agronomic practices can affect bioavailability and crop accumulation of heavy metals, thus influencing the thresholds for assessing dietary toxicity of heavy metals in the food chain (Yousaf et al. 2016).

\section{Conclusions and prospects}

In these last years, evidence is provided on the interesting molecular effects of polyphenol-rich foods beyond their role as antioxidants. Accordingly, it has been shown that flavonoids can modulate the activity of enzymes involved in the metabolism of arachidonic acid and that flavonoids-induced inhibition of these enzymes may decrease the production of prostaglandins, leukotrienes, and peroxynitrate, deleterious mediators of inflammation (Sies 2010, Hollman et al. 2011). Interestingly, in vitro experiments suggested that tea polyphenols increase the activity of the enzyme producing nitric oxide in blood vessel endothelium, thus having an important influence on the so called flow-mediated dilation, a physiological vascular response to transient ischemia (Anter et al. 2004). Currently, research looks with great interest to nutritional "omics" technologies for elucidating the possible role of bioactive food components in health promotion. (Kakkoura et al. 2017, Vázquez-Fresno et al. 2015). Measurement of the food metabolome, indeed, could provide important insights into the relations between dietary exposure, food composition, and the risk of major chronic diseases.

The MD is widely considered a sustainable diet model that presents a very low environmental footprint, promotes biodiversity and protects human health and well-being (Alsaffar 2016, De Boer et al. 2007). However, we must not ignore the emerging and serious global aspects that might convert the traditional MD pattern into a theoretical eating model far away from that described by Keys. 


\section{References}

Alsaffar AA. Sustainable diets: The interaction between food industry, nutrition, health and the environment. Food Sci Technol Int. 2016;22(2):102-111.

Andersen LF, Jacobs DR Jr, Carlsen MH, Blomhoff R. Consumption of coffee is associated with reduced risk of death attributed to inflammatory and cardiovascular diseases in the Iowa Women's Health Study. Am J Clin Nutr. 2006;83(5):1039-1046.

Anter E, Thomas SR, Schulz E, Shapira OM, Vita JA, Keaney JF Jr. Activation of endothelial nitric-oxide synthase by the p38 MAPK in response to black tea polyphenols. J Biol Chem. 2004;279(45):46637-46643.

Aparicio-Soto M, Sánchez-Hidalgo M, Rosillo MÁ, Castejón ML, Alarcón-de-laLastra C. Extra virgin olive oil: a key functional food for prevention of immuneinflammatory diseases. Food Funct. 2016;7 (11): 4492-4505.

Asif M, Rooney LW, Ali R, Riaz MN. Application and opportunities of pulses in food system: a review. Crit Rev Food Sci Nutr. 2013;53(11):1168-1179.

Bach-Faig A, Berry EM, Lairon D, Reguant J, Trichopoulou A, Dernini S, Medina FX, Battino M, Belahsen R, Miranda G, SerraMajem L; Mediterranean Diet Foundation Expert Group. Mediterranean diet pyramid today. Science and cultural updates. Public Health Nutr. 2011;14(12A):2274-2284.

Baroni L, Cenci L, Tettamanti M, Berati M. Evaluating the environmental impact of various dietary patterns combined with different food production systems. Eur J Clin Nutr. 2007;61(2):279-286.
Belahsen R. Nutrition transition and food sustainability. Proc Nutr Soc. 2014;73(3): 385-388.

Bower A, Marquez S, de Mejia EG. The Health Benefits of Selected Culinary Herbs and Spices Found in the Traditional Mediterranean Diet. Crit Rev Food Sci Nutr. 2016;56(16):2728-2746.

Cabrera C, Artacho R, Gimenez R. Beneficial effects of green tea-a review. $\mathrm{J}$ Am Coll Nutr. 2006;25(2):79-99.

Calcabrini C, De Bellis R, Mancini U, Cucchiarini L, Stocchi V, Potenza L. Protective Effect of Juglans regia L. Walnut Extract Against Oxidative DNA Damage. Plant Foods Hum Nutr. 2017; doi: 10.1007/s11130-017-0609-2.

Caretto A, Lagattolla V. Non-communicable diseases and adherence to Mediterranean diet. Endocr Metab Immune Disord Drug Targets. 2015;15(1):10-7.

Carlsen MH, Halvorsen BL, Holte K, Bøhn SK, Dragland S, Sampson L, Willey C, Senoo H, Umezono Y, Sanada C, Barikmo I, Berhe N, Willett WC, Phillips KM, Jacobs DR Jr, Blomhoff R. The total antioxidant content of more than 3100 foods, beverages, spices, herbs and supplements used worldwide. Nutr J. 2010;9:3.

Castellani GC, Menichetti G, Garagnani P, Giulia Bacalini M, Pirazzini C, Franceschi C, Collino S, et al. Systems medicine of inflammaging. Brief Bioinform. 2016;17(3): 527-540.

Chiuve SE, Fung TT, Rimm EB, Hu FB, McCullough ML, Wang M, Stampfer MJ, Willett WC Alternative dietary indices both strongly predict risk of chronic disease. J Nutr. 2012;142(6):1009-1018. 
Chrysohoou C, Panagiotakos DB, Pitsavos C, Das UN, Stefanadis C. Adherence to the Mediterranean diet attenuates inflammation and coagulation process in healthy adults: The ATTICA Study. J Am Coll Cardiol. 2004;44(1):152-158.

Ciancarelli I, Di Massimo C, De Amicis D, Pistarini C, Tozzi Ciancarelli MG. Uric Acid and $\mathrm{Cu} / \mathrm{Zn}$ superoxide dismutase: potential strategies and biomarkers in functional recovery of post-acute ischemic stroke patients after intensive neurorehabilitation. Curr Neurovasc Res. 2015;12(2):120-127.

Ciancarelli I, De Amicis D, Di Massimo C, Pistarini C, Tozzi Ciancarelli MG. Mean Platelet Volume During Ischemic Stroke is a Potential Pro-inflammatory Biomarker in the Acute Phase and During Neurorehabilitation Not Directly Linked to Clinical Outcome. Curr Neurovasc Res. 2016;13(3):177-183.

Colomer R, Menéndez JA. Mediterranean diet, olive oil and cancer. Clin Transl Oncol. 2006;8(1):15-21.

Cordova AC, Jackson LS, Berke-Schlessel DW, Sumpio BE. The cardiovascular protective effect of red wine. J Am Coll Surg. 2005;200(3):428-439.

Dai J, Jones DP, Goldberg J, Ziegler TR, Bostick RM, Wilson PW, Manatunga AK, Shallenberger L, Jones L, Vaccarino V. Association between adherence to the Mediterranean diet and oxidative stress. Am J Clin Nutr. 2008;88(5):1364-1370.

D’Archivio M, Filesi C, Di Benedetto R, Gargiulo R, Giovannini C, Masella R. Polyphenols, dietary sources and bioavailability. Ann Ist Super Sanità. 2007;43(4):348-361.

Davinelli S, Scapagnini G. Polyphenols: a promising nutritional approach to prevent or reduce the progression of prehypertension.
High Blood Press Cardiovasc Prev. 2016;23(3):197-202.

Davis CR, Hodgson JM, Woodman R, Bryan J, Wilson C, Murphy KJ. A Mediterranean diet lowers blood pressure and improves endothelial function: results from the MedLey randomized intervention trial. Am J Clin Nutr. 2017;doi:10.3945/ajcn.116. 146803.

De Boer J, Hoogland CT, Boersema JJ. Towards more sustainable food choices: value priorities and motivational orientations. Food Qual Prefer. 2007;18:985996.

De Lange DW, van Golde PH, Scholman WLG, Kraaijenhagen RJ, Akkerman JWN, van de Wiel A. Red wine and red wine polyphenolic compounds but not alcohol inhibit ADP-induced platelet aggregation. Eur J Intern Med. 2003;14(6):361-366.

De Lorgeril M, Salen P, Martin JL, Monjaud I, Delaye J, Mamelle N. Mediterranean diet, traditional risk factors, and the rate of cardiovascular complications after myocardial infarction: final report of the Lyon Diet Heart Study. Circulation. 1999;99(6):779-785.

Del Rio D, Costa LG, Lean ME, Crozier A. Polyphenols and health: what compounds are involved? Nutr Metab Cardiovasc Dis. 2010;20(1):1-6.

Dernini S, Berry EM. Mediterranean diet: from a healthy diet to a sustainable dietary pattern. Front Nutr. 2015;2:15.

Di Massimo C, Scarpelli P, Di Lorenzo N, Caimi G, di Orio F, Tozzi Ciancarelli MG. Impaired plasma nitric oxide availability and extracellular superoxide dismutase activity in healthy humans with advancing age. Life Sci. 2006;78(11):1163-1167. 
Donini LM, Dernini S, Lairon D, SerraMajem L, Amiot MJ, Del Balzo V, Giusti AM, Burlingame B, Belahsen R, Maiani G, Polito A, Turrini A, Intorre F, Trichopoulou A, Berry EM. A Consensus Proposal for Nutritional Indicators to Assess the Sustainability of a Healthy Diet: The Mediterranean Diet as a Case Study. Front Nutr. 2016;3:37.

Esposito K, Marfella R, Ciotola M, Di Palo C, Giugliano F, Giugliano G, D'Armiento M, D'Andrea F, Giugliano D. Effect of a Mediterranean-style diet on endothelial dysfunction and markers of vascular inflammation in the metabolic syndrome: a randomized trial. JAMA. 2004;292(12): 1440-1446.

Fazel-Tabar Malekshah A, Zaroudi M, Etemadi A, Islami F, Sepanlou S, Sharafkhah M, Keshtkar AA, Khademi H, Poustchi H, Hekmatdoost A, Pourshams A, Feiz-Sani A, Jafari E, Kamangar F, Dawsey SM, Abnet CC, Pharoah PD, Berennan PJ, Boffetta P, Esmaillzadeh A, Malekzadeh R. The combined effects of healthy lifestyle behaviors on all-cause mortality: The Golestan cohort study. Arch Iran Med. 2016;19(11):752-761.

Fitó M, Guxens M, Corella D, Sáez G, Estruch R, de la Torre R, Francés F,Cabezas C, López-Sabater Mdel C, Marrugat J, García-Arellano A, Arós F,Ruiz-Gutierrez V, Ros E, Salas-Salvadó J, Fiol M, Solá R, Covas MI; PREDIMED Study Investigators. Effect of a traditional Mediterranean diet on lipoprotein oxidation: a randomized controlled trial. Arch Intern Med. 2007;167(11):1195-1203.

Fung TT, Rimm EB, Spiegelman D, Rifai N, Tofler GH, Willett WC, Hu FB. Association between dietary patterns and plasma biomarkers of obesity and cardiovascular disease risk. Am J Clin Nutr. 2001;73(1):6167.
Fung TT, Rexrode KM, Mantzoros CS, Manson JE, Willett WC, Hu FB. Mediterranean diet and incidence of and mortality from coronary heart disease and stroke in women. Circulation. 2009;119(8): 1093-1100.

Fuster V, Kelly BB. Promoting cardiovascular health in the developing world: a critical challenge to achieve global health. Washington, DC; National Academies Press (US); 2010.

Garnett T, Appleby MC, Balmford A, Bateman IJ, Benton TG, Bloomer P, et al. Agriculture. Sustainable intensification in agriculture: premises and policies. Science. 2013;341(6141):33-34.

Gayathri R, Ruchi V, Mohan V. Impact of nutrition transition and resulting morbidities on economic and human development. Curr Diabetes Rev. 2016;Aug 31.

Goldberg DM, Yan J, Soleas GJ. Absorption of three wine-related polyphenols in three different matrices by healthy subjects. Clin Biochem. 2003;36(1):79-87.

Gostin LO, Abou-Taleb H, Roache SA, Alwan A. Legal priorities for prevention of non-communicable diseases: innovations from WHO's Eastern Mediterranean region. Public Health. 2017;144:4-12.

Gresele P, Pignatelli P, Guglielmini G, Carnevale R, Mezzasoma AM, Ghiselli A, Momi S, Violi F. Resveratrol, at concentrations attainable with moderate wine consumption, stimulates human platelet nitric oxide production. J Nutr. 2008;138(9):1602-1608.

Halliwell B, Gutteridge JMC. Free Radicals in Biology and Medicine. Oxford University Press, London, UK, 3rd edition,1999.

Harmon BE, Boushey CJ, Shvetsov YB, Ettienne R, Reedy J, Wilkens LR, Le 
Marchand L, Henderson BE, Kolonel LN. Associations of key diet-quality indexes with mortality in the Multiethnic Cohort: the Dietary Patterns Methods Project. Am J Clin Nutr. 2015;101(3):587-597.

Hawkes C. Uneven dietary development: linking the policies and processes of globalization with the nutrition transition, obesity and diet-related chronic diseases. Globalization and Health. 2006;2:4-21.

Hernáez Á, Castañer O, Goday A, Ros E, Pintó X, Estruch R, Salas-Salvadó J, Corella $\mathrm{D}$, Arós F, Serra-Majem L, MartínezGonzález MÁ, Fiol M, Lapetra J, de la Torre R, López-Sabater MC, Fitó M. The Mediterranean Diet decreases LDL atherogenicity in high cardiovascular risk individuals: a randomized controlled trial. Mol Nutr Food Res. 2017; doi: 10.1002/mnfr.201601015.

Hollman PC, Cassidy A, Comte B, Heinonen M, Richelle M, Richling E, Serafini M, Scalbert A, Sies H, Vidry S. The biological relevance of direct antioxidant effects of polyphenols for cardiovascular health in humans is not established. J Nutr. 2011;141(5):989S-1009S.

Horgan GW, Perrin A, Whybrow S, Macdiarmid JI. Achieving dietary recommendations and reducing greenhouse gas emissions: modelling diets to minimise the change from current intakes. Int J Behav Nutr Phys Act. 2016;13:46.

Huang WY, Davidge ST, Wu J. Bioactive natural constituents from food sourcespotential use in hypertension prevention and treatment. Crit Rev Food Sci Nutr. 2013;53(6):615-630.

International Food Information Council. Functional foods. http://www.foodinsight. org/Content/3842/Final\%20Functional\%20
Foods\%20Backgrounder.pdf. Published July 2011. Accessed October 24, 2012.

Iqbal, R, Anand S, Ounpuu S, Islam S, Zhang X, Rangarajan S, Chifamba J, AlHinai A, Keltai M, Yusuf S. Dietary patterns and the risk of acute myocardial infarction in 52 countries: results of the INTERHEART study. Circulation. 2008;118 (19):1929-1937.

Iriti M, Vitalini S. Health-promoting effects of traditional Mediterranean Diets - A review. Pol J Food Nutr Sci. 2012;62(2):7176.

Islam Eu, Yang XE, He ZL, Mahmood Q. Assessing potential dietary toxicity of heavy metals in selected vegetables and food crops. J Zhejiang Univ Sci B. 2007;8(1):1-13.

Jacques PF, Tucker KL. Are dietary patterns useful for understanding the role of diet in chronic disease? Am J Clin Nutr. 2001;73(1):1-2.

Kakkoura MG, Sokratous K, Demetriou CA, Loizidou MA, Loucaides G, Kakouri E, Hadjisavvas A, Kyriacou K. Mediterranean diet-gene interactions: A targeted metabolomics study in Greek-Cypriot women. Mol Nutr Food Res. 2017;61(4). doi: 10.1002/mnfr.201600558.

Katz DL, Meller S. Can we say what diet is best for health? Annu Rev Public Health. 2014;35:83-103.

Keys A, Menotti A, Karvonen MJ, Blackburn H, Buzina R, Djordjevic BS, Dontas AS, Fidanza F, Keys MH, et al. The diet and 15-year death rate in the seven countries study. Am J Epidemiol. 1986;124(6):903-915.

Khaw KT, Wareham N, Bingham S, Welch A, Luben R, Day N. Combined impact of health behaviours and mortality in men and 
women: the EPIC-Norfolk prospective population study. PLoS Med. 2008;5(3):e70.

Knight A, Bryan J, Murphy K. Is the Mediterranean diet a feasible approach to preserving cognitive function and reducing risk of dementia for older adults in Western countries? New insights and future directions. Ageing Res Rev. 2016;25:85101.

Knoops KT, de Groot, LC, Kromhout D, Perrin AE, Moreiras-Varela O, Menotti A, van Staveren WA. Mediterranean diet, lifestyle factors, and 10-year mortality in elderly European men and women: the HALE project. JAMA. 2004;292(12):14331439.

Koloverou E, Panagiotakos DB, Pitsavos C, Chrysohoou C, Georgousopoulou EN, Grekas A, Christou A, Chatzigeorgiou M, Skoumas I, Tousoulis D, Stefanadis C; ATTICA Study Group. Adherence to Mediterranean diet and 10-year incidence (2002-2012) of diabetes: correlations with inflammatory and oxidative stress biomarkers in the ATTICA cohort study. Diabetes Metab Res Rev. 2016;32(1):73-81.

Kones R. Is prevention a fantasy, or the future of medicine? A panoramic view of recent data, status, and direction in cardiovascular prevention. Ther Adv Cardiovasc Dis. 2011;5(1):61-81.

Korre M, Tsoukas MA , Frantzeskou E, Yang J, Kales SN. Mediterranean Diet and Workplace Health Promotion. Curr Cardiovasc Risk Rep. 2014;8(12):416.

Lacoppidan SA, Kyrø C, Loft S, Helnæs A, Christensen J, Hansen CP, Dahm CC, Overvad K, Tjønneland A, Olsen A. Adherence to a Healthy Nordic Food Index Is Associated with a Lower Risk of Type-2 Diabetes--The Danish Diet, Cancer and
Health Cohort Study. Nutrients. 2015;7(10):8633-8644.

Lairon D. Intervention studies on Mediterranean diet and cardiovascular risk. Mol Nutr Food Res. 2007;51(10):1209-1214.

Leclercq C, Arcella D, Piccinelli R, Sette S, Le Donne C, Turrini A; INRAN-SCAI 200506 Study Group. The Italian National Food Consumption Survey INRAN-SCAI 200506: main results in terms of food consumption. Public Health Nutr. 2009;12(12):2504-2532.

Lloyd-Jones D, Adams R, Carnethon M, De Simone G, Ferguson TB, Flegal K, Ford E, Furie K, Go A, Greenlund K, Haase N, et al. Heart disease and stroke statistics - 2009 update: a report from the American Heart Association Statistics Committee and Stroke Statistics Subcommittee. Circulation. 2009;119(3):480-486.

Lloyd-Jones DM, Hong Y, Labarthe D, Mozaffarian D, Appel LJ, Van Horn L, Greenlund K, Daniels S, Nichol G, Tomaselli GF, et al. Defining and setting national goals for cardiovascular health promotion and disease reduction: the American Heart Association's strategic impact goal through 2020 and beyond. Circulation. 2010;121(4):586-613.

Loef M, Walach $\mathrm{H}$. The combined effects of healthy lifestyle behaviors on all cause mortality: a systematic review and metaanalysis. Prev Med. 2012;55(3):163-170.

Malik A, Mukhtar H. Prostate cancer prevention through pomegranate fruit. Cell Cycle. 2006;5(4):371-373.

Mangge H, Becker K, Fuchs D, Gostner JM. Antioxidants, inflammation and cardiovascular disease. World J Cardiol. 2014;6(6):462-477. 
Martínez-González MÁ, Ruiz-Canela M, Hruby A, Liang L, Trichopoulou A, Hu FB. Intervention Trials with the Mediterranean Diet in Cardiovascular Prevention: Understanding Potential Mechanisms through Metabolomic Profiling. J Nutr. 2016;pii: jn219147.

McKay DL, Chen CY, Yeum KJ, Matthan NR, Lichtenstein AH, Blumberg JB. Chronic and acute effects of walnuts on antioxidant capacity and nutritional status in humans: a randomized, cross-over pilot study. Nutr J. 2010;9:21.

Medina-Remón A, Casas R, TressserraRimbau A, Ros E, Martínez-González MA, Fitó M, Corella D, Salas-Salvadó J, Lamuela-Raventos RM, Estruch R; PREDIMED Study Investigators. Polyphenol intake from a Mediterranean diet decreases inflammatory biomarkers related to atherosclerosis: a substudy of the PREDIMED trial. $\mathrm{Br} \mathrm{J}$ Clin Pharmacol. 2017;83(1):114-128.

Mehio Sibai A, Nasreddine L, Mokdad AH, Adra N, Tabet M, Hwalla N. Nutrition transition and cardiovascular disease risk factors in Middle East and North Africa countries: reviewing the evidence. Ann Nutr Metab. 2010;57(3-4):193-203.

Menotti A, Alberti-Fidanza A, Fidanza F, Lanti M, Fruttini D. Factor analysis in the identification of dietary patterns and their predictive role in morbid and fatal events. Public Health Nutr. 2012;15(7):1232-1239.

Mertens E, Markey O, Geleijnse JM, Lovegrove JA, Givens DI. Adherence to a healthy diet in relation to cardiovascular incidence and risk markers: evidence from the Caerphilly Prospective Study. Eur J Nutr. 2017; doi:10.1007/s00394-017-1408-0.

Miranda AM, Steluti J, Fisberg RM, Marchioni DM. Dietary intake and food contributors of polyphenols in adults and elderly adults of Sao Paulo: a populationbased study. Br J Nutr. 2016;115(6):10611070.

Niebylski ML, Redburn KA, Duhaney T, Campbell NR. Healthy food subsidies and unhealthy food taxation: A systematic review of the evidence. Nutrition. 2015;31(6):787-795.

Noah A, Truswell AS. There are many Mediterranean diets. Asia Pac J Clin Nutr. 2001;10(1):2-9.

Oliviero F, Spinella P, Fiocco U, Ramonda R, Sfriso P, Punzi L. How the Mediterranean diet and some of its components modulate inflammatory pathways in arthritis. Swiss Med Wkly. 2015;145:w14190.

Ortega RM. Importance of functional foods in the Mediterranean diet. Public Health Nutrition. 2006;9(8A):1136-1140.

Owolabi M, Miranda JJ, Yaria J, Ovbiagele B. Controlling cardiovascular diseases in low and middle income countries by placing proof in pragmatism. BMJ Glob Health. 2016;1(3). pii: e000105.

Panagiotakos DB, Pitsavos C, Polychronopoulos E, Chrysohoou C, Zampelas A,Trichopoulou A. Can a Mediterranean diet moderate the development and clinical progression of coronary heart disease? A systematic review. Med Sci Monit. 2004;10:RA193-198.

Panagiotakos DB, Chrysohoou C, Siasos G, Zisimos K, Skoumas J, Pitsavos C, Stefanadis C. Sociodemographic and lifestyle statistics of oldest old people (>80 years) living in ikaria island: the ikaria study. Cardiol Res Pract. 2011;doi:10.4061/2011/679187.

Pellegrini N, Serafini M, Colombi B, Del Rio D, Salvatore S, Bianchi M, Brighenti F. 
Total antioxidant capacity of plant foods, beverages and oils consumed in Italy assessed by three different in vitro assays. J Nutr. 2003;133(9):2812-2819.

Pellegrini N, Serafini M, Salvatore S, Del Rio D, Bianchi M, Brighenti F. Total antioxidant capacity of spices, dried fruits, nuts, pulses, cereals and sweets consumed in Italy assessed by three different in vitro assays. Mol Nutr Food Res. 2006;50(11):1030-1038.

Preedy VR, Watson RR, eds. The Mediterranean Diet: An Evidence-Based Approach. Academic Press; 2015.

Psaltopoulou T, Kyrozis A, Stathopoulos P, Trichopoulos D, Vassilopoulos D, Trichopoulou A. Diet, physical activity and cognitive impairment among elders: the EPIC-Greece cohort (European Prospective Investigation into Cancer and Nutrition). Public Health Nutr. 2008;11 (10):1054-1062.

Psaltopoulou T, Sergentanis TN, Panagiotakos DB, Sergentanis IN, Kosti R, Scarmeas N. Mediterranean diet, stroke, cognitive impairment, and depression: a meta-analysis. Ann Neurol. 2013;74(4):580591.

Reedy J, Krebs-Smith SM, Miller PE, Liese AD, Kahle LL, Park Y, Subar AF. Higher diet quality is associated with decreased risk of all cause, cardiovascular disease, and cancer mortality among older adults. J Nutr. 2014;144(6):881-889.

Renaud S, de Lorgeril M. Wine, alcohol, platelets, and the French paradox for coronary heart disease. Lancet. 1992;339(8808):1523-1526.

Ros E, Nunez I, Perez-Heras A, Serra M, Gilabert R, Casals E, Deulofeu R. A walnut diet improves endothelial function in hypercholesterolemic subjects: a randomized crossover trial. Circulation. 2004;109 (13):1609-1614.

Sacks FM, Appel LJ, Moore TJ, Obarzanek E, Vollmer WM, Svetkey LP, Bray GA, Vogt TM, Cutler JA, Windhauser MM, Lin $\mathrm{PH}$, Karanja N. A dietary approach to prevent hypertension: a review of the Dietary Approaches to Stop Hypertension (DASH) Study. Clin Cardiol. 1999;22(7Suppl):III6-10.

Sáez-Almendros S, Obrador B, Bach-Faig A, Serra-Majem L. Environmental footprints of Mediterranean versus Western dietary patterns: beyond the health benefits of the Mediterranean diet. Environ Health. 2013;12:118.

Schulze MB, Hu FB. Dietary patterns and risk of hypertension, type 2 diabetes mellitus, and coronary heart disease. Curr Atheroscler Rep 2002;4(6):462-467.

Schwingshackl L, Hoffmann G. Diet quality as assessed by the Healthy Eating Index, the Alternate Healthy Eating Index, the Dietary Approaches to Stop Hypertension Score, and health outcomes: a systematic review and meta-analysis of cohort studies. J Acad Nutri Diet. 2015;115(5):780-800.

Sette S, Le Donne C, Piccinelli R, Arcella D, Turrini A, Leclercq C; INRAN-SCAI 200506 Study Group. The third Italian National Food Consumption Survey, INRAN-SCAI 2005-06--part 1: nutrient intakes in Italy. Nutr Metab Cardiovasc Dis. 2011;21(12):922-932.

Sies H. Polyphenols and health: update and perspectives. Arch Biochem Biophys 2010;501(1):2-5.

Sofi F, Cesari F, Abbate R, Gensini GF, Casini A. Adherence to Mediterranean diet and health status: meta-analysis. BMJ. 2008;337:a1344. 
Sofi F, Macchi C, Abbate R, Gensini GF, Casini A. Mediterranean diet and health status: an updated meta-analysis and a proposal for a literature-based adherence score. Public Health Nutr. 2014;17(12): 2769-2782.

Starr ME, Evers BM, Saito H. Ageassociated increase in cytokine production during systemic inflammation: adipose tissue as a major source of IL-6. J Gerontol A Biol Sci Med Sci. 2009;64(7):723-730.

Tapiero H, Tew KD, Ba GN, Mathé G. Polyphenols: do they play a role in the prevention of human pathologies? Biomed Pharmacother. 2002;56(4):200-207.

Tarascou I , Souquet JM , Mazauric JP , Carrillo S, Coq S, Canon F, Fulcrand $\mathrm{H}$, Cheynier V. The hidden face of food phenolic composition. Archi Biochem Biophys 2010;501(1):16-22.

Tozzi Ciancarelli MG, Di Massimo C, De Amicis D, Ciancarelli I, Carolei A. Moderate consumption of red wine and human platelet responsiveness. Thromb Res 2011;128(2):124-129.

Traill WB, Mazzocchi M, Shankar B, Hallam D. Importance of government policies and other influences in transforming global diets. Nutr Rev. 2014;72(9):591-604.

Tsang C, Higgins S, Duthie GG, Duthie SJ, Howie M, Mullen W, Lean EJ, Crozier A. The influence of moderate red wine consumption on antioxidant status and indices of oxidative stress associated with $\mathrm{CHD}$ in healthy volunteers. $\mathrm{Br} \mathrm{J}$ Nutr. 2005;93(2):233-240.

Vallverdú-Queralt A, Regueiro J, MartínezHuélamo M, Rinaldi AlvarengaJF, Leal LN, Lamuela-Raventos RM. A comprehensive study on the phenolic profile of widely used culinary herbs and spices: rosemary, thyme, oregano, cinnamon, cumin and bay. Food Chem. 2014;154:299-307.

van Dam RM, Li T, Spiegelman D, Franco $\mathrm{OH}, \mathrm{Hu}$ FB. Combined impact of lifestyle factors on mortality: prospective cohort study in US women. BMJ. 2008;337:a1440.

Vareiro D, Bach-Faig A, Raido' Quintana B, Bertomeu I, Buckland G, Vaz de Almeida MD, Serra-Majem L. Availability of Mediterranean and non-Mediterranean foods during the last four decades: comparison of several geographical areas. Public Health Nutr. 2009;12(9A):1667-1675.

Vázquez-Fresno R, Llorach R, Urpi-Sarda M, Lupianez-Barbero A, Estruch M, Corella D, Fitó M, Arós F, Ruiz-Canela M, SalasSalvadó J, Andres-Lacueva C. Metabolomic pattern analysis after mediterranean diet intervention in a nondiabetic population: a 1and 3-year follow-up in the PREDIMED study. J Proteome Res. 2015;14(1):531-540.

Vogel RA, Corretti MC, Plotnick GD. The postprandial effect of components of the Mediterranean diet on endothelial function. J Am Coll Cardiol. 2000;36(5):1455-1460.

Watson D, Lorenz U, St. Hansen M, Szlezak J, Zoboli R, Kuhndt M, et al. European Environment Agency (EEA); towards a Set of Indicators on Sustainable Consumption and Production (scp) for EEA Reporting. European Topic Centre on Sustainable Consumption and Production (ETC/SCP) Working Paper 1/2010. Copenhagen 2010.

World Cancer Research Fund/American Institute for Cancer Research: Food, Nutrition, Physical Activity and the Prevention of Cancer: a Global Perspective American Institute of Cancer Research, Washington DC 2007.

World Heart Organization Study Group. Diet, Nutrition and the Prevention of 
Medical Research Archives, Vol. 5, Issue 7, July 2017

Mediterranean Diet and Health Promotion: evidence and current concerns

Chronic Diseases. Geneva, Switzerland: communicable diseases 2013-2020. World heart Organization, Technical Report Series, 797, 1990.

World Health Organization. Diet, nutrition and the prevention of chronic diseases. WHO Tech Rep Ser. 2003;1-60.

World Health Organization. Global status report on non-communicable diseases 2010. Geneva: World Health Organization;2011.

World Health Organization. Global Action Plan for the Prevention and Control of non-

Wirt A, Collins CE. Diet quality-what is it and does it matter? Public Health Nutr. 2009;12(12):2473-2492.

Yousaf B, Amina, Liu G, Wang R, Imtiaz M, Rizwan MS, Zia-Ur-Rehman M, Qadir A, Si Y. The importance of evaluating metal exposure and predicting human health risks in urban-periurban environments influenced by emerging industry. Chemosphere. 2016;150:79-89. 